\title{
Konstruksi Sosial Media Komunikasi Instagram Terhadap Pola Pikir Perilaku Mahasiswa Pendidikan Sosiologi
}

\author{
Nurbaya \\ Nursalam \\ Universitas Muhammadiyah Makassar \\ nursalam@unismuh.ac.id
}

\begin{abstract}
ABSTRAK
Perkembangan teknologi informasi dan komunikasi seperti media massa khususnya media instagram yang menyebabkan terjadi perubahan secara cepat dimanamana. Media massa khusunya media instagram sedikit demi sedikit membawa masuk mahasiswa pendidikan sosiologi. Tujuan penelitian untuk mengatahui bagaimana penggunaan media social instagram medorong perubahan pola pikir perilaku mahasiswa pendidikan sosiologi.untuk mencapai tujuan penelitian ini, maka penelitian menggunakan metode kualitatif dengan dasar penelitian studi kasus dan tipe penelitian deskriptif yaitu suatu model penelitian yang bertujuan untuk penelitian yang dilakukan secara intensif terperinci dan mendalam. Jenis penelitian ini adalah penelitian sosial budaya (PSB) dengan tipe deskriptif kualitatif, yaitu memberikan gambaran tentang pola pikir perilaku mahasiswa mengenai media Instagram tersebut. Pengumpulan data dalam penelitian ini dilakukan dengan cara observasi, wawancara dan dokumentasi. Informan dalam penelitian ini dipilih dengan penentuan informan secara availability sampling atau biasa dikenal dengan aksidental yaitu teknik pengambilan informan secara kebetulan dan tidak menggunakan kriteria atau pertimbangan tertentu. Hasil penelitian ini adalah bahwa Instagram merupakan media yang memberi kemudahan cara berbagi secara online oleh fofto-foto, video dan juga layanan jejaring sosial yang dapat digunakan pengguna untuk menggambil dan membagi keteman mereka ataupun mejajahkan produk mereka melalui media Instagram tersebut.
\end{abstract}

Kata Kunci : Pola Pikir, Perilaku Mahasiswa Pendidikan Sosiologi

\section{PENDAHULUAN}

Perkembangan zaman terus melaju pesat. Teknologi akses komunikasi semakin maju memudahkan masyarakat dalam bersosialisasi. Kemudahan-kemudahan tersebut ditawarkan melalui munculnya banyak media sosial yang dapat digunakan oleh semua orang untuk berinteraksi atau sekedar mencari hiburan melalui dunia maya. Kemajuan teknologi komunikasi ternyata dimanfaatkan juga oleh mahasiswa untuk megaktualisasikan diri, belajar, dan bermain. Melalui media sosial, banyak remaja yang memanfaatkannya sebagai sarana berinteraksi dengan teman, berbagi tugas-tugas sekolah, bermain game, dan atau sekedar untuk mengisi waktu luang. 
Namun ternyata, kemudahan-kemudahan yang ditawarkan akibat perkembangan teknologi komunikasi, selain banyak membawa dampak positif juga membawa pengaruh negatif terhadap waktu bermain dan belajar remaja. Adanya media sosial digunakan oleh 27 juta anak dan remaja di Indonesia ini membuat memudarnya batasan-batasan perilaku yang dilakukan remaja. Kemudahan akses media sosial ternyata mengganggu waktu bermain dan belajar. Hal tersebut terjadi karena banyak aspek seperti tingkat konformitas remaja, kurangnya pengawasan orang tua, dan kurang berperannya pemerintah yang sebenarnya memiliki otoritas untuk mengendalikan penggunaan media sosial.

Jejaring sosial merupakan situs dimana setiap orang bisa membuat web page pribadi, kemudian terhubung dengan teman-teman untuk berbagi informasi dan berkomunikasi. Jejaring sosial terbesar antara lain, Facebook, Myspace, Instagram dan Twitter. Pesatnya perkembangan teknologi informasi dan komunikasi seperti media massa khususnya media instagram, menyebabkan terjadi perubahan secara cepat dimanamana. Media massa khusunya media instagram sedikit demi sedikit membawa masuk mahasiswa pendidikan sosiologi angkatan 2014 di Universitas Muhammadiyah Makassar ke suatu pola pikir dan perilaku yang baru.

Instagram sebagai media komunikasi dimana dalam media instagram seseorang tidak melakukan komunikasi secara langsung, dimana orang melakukan komunikasi melalui chat atau saling berkomentar melalui gambar atau foto yang di unggah di instagram, dan juga memperluas jaringan pertemanan, mahasiswa akan menjadi lebih mudah berteman dengan orang lain diseluruh dunia meski sebagian besar di antaranya belum pernah mereka temui secara langsung.

Pesan atau informasi yang disampaikan oleh media sosial khususnya media instagram bisa jadi mendukung mahasiswa menjadi lebih baik, membuat mahasiswa merasa senang akan diri mereka, merasa cukup atau sebaliknya mengempiskan kepercayaan dirinya atau merasa rendah dari yang lain. Pergeseran pola pikir dan perilaku yang diakibatkan oleh media massa khususnya media instagram dapat terjadi di lingkungan keluarga, sekolah, dan dalam kehidupan bermasyarakat. Wujud perubahan pola pikir dan perilaku lainnya yaitu gaya hidup. Perubahan gaya hidup dalam hal peniruan atau imitasi secara berlebihan terhadap diri seorang figur yang sedang diidolakan berdasarkan informasi yang diperoleh dari media. Biasanya seseorang akan meniru segala sesuatu yang berhubungan dengan idolanya tersebut baik dalam hal berpakaian, berpenampilan, potongan rambutnya ataupun cara berbicara yang mencerminkan diri idolanya. 
Hal tersebut diatas cenderung lebih berpengaruh terhadap generasi muda. Secara sosio-psikologis, arus informasi yang terus menerpa kehidupan kita akan menimbulkan berbagai pengaruh terhadap perkembangan jiwa, khususnya untuk anakanak dan remaja. Pola perilaku mereka, sedikit demi sedikit dipengaruhi oleh apa yang mereka terima yang mungkin melenceng dari tahap perkembangan jiwa maupun normanorma yang berlaku.

\section{LANDASAN TEORI}

Konstruksi sosial merupakan teori sosiologi kontemporer, dicetuskan oleh Peter L. Berger dan Thomas Luckmann. Teori ini merupakan suatu kajian teoritis dan sistematis mengenai sosiologi pengetahuan (penalaran teoritis yang sistematis), bukan merupakan suatu tinjauan historis mengenai perkembangan disiplin ilmu. Susbtansi teori dan pendekatan konstruksi sosial atas realitas dari Bergerdan Luckmann adalah pada proses simultan yang terjadi secara alamiah melalui bahasa dalam kehidupan sehari-hari pada sebuah komunitas primer dan semisekunder. Basis sosial teori dan pendekatan ini adalah transisi-modern di Amerikapada sekitar tahun 1960-an, dimana media massa belum menjadi sebuah fenomena yang menarik untuk dibicarakan. Dengan demikian Berger danLuckmann tidak memasukan media massa sebagai variabel atau fenomena yangberpengaruh dalam konstruksi sosial atas realitas.

Teori dan pendekatan konstruksi sosial atas realitas Peter L. Berger dan Luckman (Bungin, 2008:14) telah direvisi dengan melihat variabel atau fenomena media massamenjadi sangat substansi dalam proses eksternalisasi, subyektivasi, dan internalisasi inilah yang kemudian dikenal sebagai "konstruksi sosial media massa". Substansi dari konstruksi sosial media massa ini adalah pada sirkulasi informasi yang cepat dan luas sehingga konstruksi sosial berlangsung dengan sangat cepat dan sebarannya merata.

Eksternalisasi, yaitu usaha pencurahan atau ekspresi diri manusia ke dalam dunia, baik dalam kegiatan mental maupun fisik. Ini sudah menjadi sifat dasar dari manusia, ia akan selalu mencurahkan diri ke tempat dimana ia berada. Manusia tidak dapat kita mengerti sebagai ketertutupan yang lepas dari dunia luarnya. Manusia berusaha menangkap dirinya, dalam proses inilah dihasilkan suatu dunia dengan kata lain, manusia menemukan dirinya sendiri dalam suatu dunia. Objektivasi, yaitu hasil yang telah dicapai baik mental maupun fisik dari kegiatan eksternalisasi manusia tersebut. Hasil itu menghasilkan realitas objektif yang bisa jadi akan menghadapi si penghasil itu sendiri sebagai suatu faktisitas yang berada di luar dan berlainan dari manusia yang 
menghasilkannya. Lewat proses objektivasi ini, masyarakat menjadi suatu realitas suigeneris. Hasil dari eksternalisasi kebudayaan itu misalnya, manusia menciptakan alat demi kemudahan hidupnya atau kebudayaan non-materiil dalam bentuk bahasa. Baik alat tadi maupun bahasa adalah kegiatan ekternalisasi manusia ketika berhadapan dengan dunia, ia adalah hasil dari kegiatan manusia. Setelah dihasilkan, baik benda atau bahasa sebagai produk eksternalisasi tersebut menjadi realitas yang objektif. Bahkan ia dapat menghadapi manusia sebagai penghasil dari produk kebudayaan. Kebudayaan yang telah berstatus sebagai realitas objektif, ada diluar kesadaran manusia, ada "di sana" bagi setiap orang. Realitas objektif itu berbeda dengan kenyataan subjektif perorangan.Ia menjadi kenyataan empiris yang bisa dialami oleh setiap orang.

Internalisasi. Proses internalisasi lebih merupakan penyerapan kembali dunia objektif ke dalam kesadaran sedemikian rupa sehingga subjektif individu dipengaruhi oleh struktur dunia sosial. Berbagai macam unsur dari dunia yang telah terobjektifkan tersebut akan ditangkap sebagai gejala realitas diluar kesadarannya, sekaligus sebagai gejala internal bagi kesadaran. Melalui internalisasi, manusia menjadi hasil dari masyarakat. Bagi Berger, realitas itu tidak dibentuk secara ilmiah, tidak juga sesuatu yang diturunkan oleh Tuhan. Tetapi sebaliknya, ia dibentuk dan dikonstruksi. Dengan pemahaman semacam ini, realitas berwajah ganda/plural.Setiap orang bisa mempunyai konstruksi yang berbeda-beda atas suatu realitas. Setiap orang yang mempunyai pengalaman, preferensi, pendidikan tertentu, dan lingkungan pergaulan atau sosial tertentu akan menafsirkan realitas sosial itu dengan konstruksinya masing-masing.

Instagram adalah media yang memberi kemudahan cara berbagi secara online oleh foto-foto, video dan juga layanan jejaring sosial yang dapat digunakan pengguna untuk mengambil dan membagi ke teman mereka. Menurut situs Instagram, aplikasi Instagram didirikan oleh Kevin Systrom dan Mike Krieger. Aplikasi ini dirilis pada Oktober 2010. Instagram merupakan aplikasi yang untuk berbagi foto atau gambar kepada teman-teman sesama pengguna instagram. Foto-foto di Instagram dapat dijadikan kenangan untuk bisa dilihat untuk kedepannya, dapat mengekspresikan keadaan yang sedang terjadi dan telah terjadi.Pengguna media sosial Instagram menginginkan reaksi dari teman-teman mereka dan saling memberikan komentar dan like dari foto maupun video yang diunggah.

Instagram sama seperti jejaring sosial lainnya, namun lebih fokus kepada foto atau pengeditan foto. Instagram adalah jejaring sosial yang dapat digunakan sebagai salah satu wadah penyaluran bagi orang- orang yang memiliki minat tentang foto. Dari penjelasan diatas dapat disimpulkan bahwa Instagram adalah jejaring sosial yang digunakan sebagi tempat menyebarkan dan berbagi informasi, berinteraksi dengan orang 
banyak, serta dapat mengenal lebih dekat dengan sesama pengguna Instagram melalui foto-foto, video yang diunggah. Dampak positifnya ialah bisa membantu bagi yang senang mengabadikan moment / peristiwa di sekelilingnya melalui foto, juga dapat menuangkan ide kreatif melalui foto atau mungkin sebagai media promosi dan informasi. Karena mengandalkan media visual tentu akan sangat bermanfaat dalam mencari suatu informasi. Aplikasi ini berbeda dengan aplikasi pengeditan foto lainnya. Banyak orang menggunakan instagram karena selain mudah menggunakannya terdapat banyak efek tambahan. Efek tersebut dapat memanipulasi wajah menjadi beda dari aslinya. Meski demikian, ada juga dampak positif yang ditimbulkan yaitu bisa merubah foto menjadi lebih bagus. Nilai plusnya adalah kita bisa share foto instagram ke facebook atau twitter dengan satu langkah mudah. Juga bisa menjalin network dengan semua teman yang ada di instagram. Dampak negatifnya, saking terlalu banyaknya menggunakan efek instagram dapat memanipulasi orang yang melihatnya.

\section{METODE PENELITIAN}

Jenis penelitian ini adalah penelitian sosial budaya (PSB) dengan tipe deskriptif kualitatif, yaitu memberikan gambaran tentang pola pikir perilaku mahasiswa mengenai media Instagram tersebut. Pengumpulan data dalam penelitian ini dilakukan dengan cara observasi, wawancara dan dokumentasi. Informan dalam penelitian ini dipilih dengan penentuan informan secara Purposive Sampling menggunakan kriteria atau pertimbangan tertentu. Tekhnik pengumpulan data yaitu observasi, dokumentasi dan wawancara mendalam. Tekhnik analisis data melalui berbagai tahapan yaitu redukdi data, penyajian data, dan penarikan kesimpulan. Sedangkan teknik keabsahan data menggunakan triangulasi sumber, waktu dan teknik.

\section{PEMBAHASAN}

Setelah menyajikan hasil penelitian, pada bagian ini peneliti akan membahasnya agar lebih jelas lagi dan dapat lebih dimengerti. Bertolak dari rumusan masalah dalam penelitian yang telah dilakukan kepada pengkajian judul Konstruksi Sosial Media Komunikasi Instagram Terhadap Pola Pikir Perilaku Mahasiswa Pendidikan Sosiologi Angkatan 2014 di Universitas Muhammadiyah Makassar (Suatu Kajian Dalam Paradigma Perilaku Sosial). Melalui kegiatan observasi, wawancara dan dokumentasi terhadap informan yang telah ditetapkan sebelumnya sebagai informan peneliti yang merupakan 
sumber informan utama. Dapat disajikan hasil penelitian dan dideskripsikan sebagai berikut :

1. Penggunaan media sosial instagram mendorong perubahan pola pikir perilaku mahasiswa pendidikan sosiologi.

Media Instagram menjadi suatu kebutuhan yang sangat penting bagi penggunanya di semua kalangan, tanpa terkecuali bagi kalangan mahasiswa sosiologi universitas muhammadiyah makassar sebagai suatu sarana komunukasi masa kini. Pengguunaan media Instagram banyak memberi perubahan pada pola pikir mahasiswa, mulai dari live style, fashion dan juga perilaku konsumtif. Instagram adalah media yang memberi kemudahan cara berbagi secara online oleh foto-foto, video dan juga layanan jejaring sosial yang dapat digunakan pengguna untuk mengambil dan membagi ke teman mereka. Instagram merupakan aplikasi yang untuk berbagi foto atau gambar kepada teman-teman sesama pengguna instagram. Foto-foto di Instagram dapat dijadikan kenangan untuk bisa dilihat untuk kedepannya, dapat mengekspresikan keadaan yang sedang terjadi dan telah terjadi. Pengguna media sosial Instagram menginginkan reaks dari teman-teman mereka dan saling memberikan komentar dan like dari foto maupun video yang diunggah.Salah satu kegunaan instagram sebagai media komunikasi dan informasi yaitu sebagai media referensi. Media referensi menggunakan teknologi komunikasi seperti menggunakan internet dan media sosial lain sebenarnya banyak. Sebagai contoh, media penelusuran google,media sosial seperti istangram dan media yang lain, wisata khususnya wisata mempengaruhi fenomena mahasiswa travelling masyarakat saat ini. Berbeda dengan sejak kemunculan Instagram foto-foto wisata menarik yang diunggah pengguna Instagramndapat mempengaruhi pengguna lainnya dan menimbulkan respon bagi para pengguna-pengguna Instagramn yang lain.

2. Faktor perubahan media sosial instagram terhadap pola pikir perilaku mahasiswa pendidikan sosiologi

Sadar atau tidak sadar media massa telah menjadi bagian penting dari kehidupan masyarakat. Melalui media massa kita dapat belajar banyak hal yang bisa di jadikan pelajaran. Berita tentang peristiwa-peristiwa yang terjadi di luar negeri maupun dalam negeri dapat diketahui dengan cepat dan mudah melalui media massa. Hal ini karena media massa memiliki kemampuan untuk memberikan informasi-informasi secara efektif. Media Instagram adalah sebuah media online, dengan para penggunanya bisa dengan mudah berpartisipasi, dan menciptakan isi karena media sosial sebagai salah satu media instagram merupakan komunikasi, media sosial tidak hanya dimanfaatkan untuk berbagi 
informasi dan inspirasi, tapi juga ekspresi diri, pencitraan diri, dan ajang curhat kehidupan bahkan keluh-kesah dan sumpah-serapah. Status terbaik di media sosial adalah update status yang informatif dan inspiratif. Media sosial banyak menjadi sebagai dunia pendidikan, dunia berbagi informasi. Adapun peran media massa ialah: pertama, media dapat memperluas cakrawala pemikiran. Kebanyakan orang yang hidup dalam masyarakat tradisional menganggap media memiliki kekuatan gaib sewaktu pertama kali mengenalnya sebab media massa dapat membuat seseorang melihat dan mengetahui tempat-tempat yang belum pernah dikunjunginya serta mengenal orang-orang yang belum pernah ditemuinya. Media telah membantu masyarakat Negara sedang berkembang mengenal kehidupan masyarakat lain sehingga mereka memperoleh pandangan baru dalam hidupnya. Media massa dapat menjadi jembatan peralihan antara masyarakat tradisional kearah masyarakat modern.Kedua, media massa dapat memusatkan perhatian. Masyarakat tradisional yang bergerak ke arah modern sedikit demi sedikit mulai menggantungkan pengetahuannya pada media massa sehingga hal-hal mengenai apa yang penting, yang berbahaya, apa yang menarik dan sebagainya berasal dari media. Akibatnya lama kelamaan masyarakat mulai meninggalkan kebiasaan atau budayanya dan menganggap budaya tersebut sebagai sesuatu yang kuno dan tidak modern.

3. Dampak perubahan media sosial instagram terhadap pola pikir perilaku mahasiswa pendidikan sosiologi.

Gaya Hidup Shopaholic Setiap kegiatan yang dilakukan oleh manusia pasti menghasilkan akibat yang dihasilkan, baik itu akibat yang berdampak positif maupun dampak negatif. Termasuk dalam pemilihan gaya hidup, akan timbul berbagai akibat. Setiap kegiatan yang dilakukan oleh manusia akan menghasilkan keuntungan dan kerugian. Begitu pula dengan gaya hidup shopaholic pada kalangan mahasiswa UNY memberikan berbagai dampak baik dan buruk. Dampak positif ataupun negatif semua tergantung bagaimana pelaku gaya hidup shopaholic menjalaninya. Berikut ada beberapa dampak positif dan dampak negatif dari perilaku shopaholic. Dampak positifnya antara lain yaitu Penghilang stress. Belanja memberikan ketenangan dan kenyamanan bagi seseorang, begitu pula dengan mahasiswa. Banyak dari mahasiswa yang menuturkan bahwa dengan berbelanja dapat menghilangkan stres dan membuat mereka bahagia. 2). Mengikuti perkembangan jaman Mahasiswa suka belanja pakaian dan kebutuhan pribadi serta kosmetik karena pada dasarnya wanita suka mengikuti perkembangan jaman terkini. Mode pakaian wanita selalu bergerak mengikuti arus dan gaya yang menjadi trend selebritis..Sedangkan dampak negatifnya diantaranya yaitu : 1) Perilaku Konsumtif : 
Shopaholic pada mahasiswa adalah perilaku konsumtif. Perilaku konsumtif adalah perilaku mengkonsumsi barang- barang yang sebenarnya kurang atau tidak diperlukan (khususnya yang berkaitan dengan respon terhadap konsumsi barang-barang sekunder, yaitu barang-barang yang tidak terlalu dibutuhkan). 2) Boros : Gaya hidup shopaholic memberikan dampak negatif yang boros bagi para mahasiswa. Sikap mahasiswa yang boros dapat dinilai dari pengeluaran mahasiswa dalam membeli barang-barang setiap bulannya. 3) Candu : Sikap candu mahasiswa terhadap gaya hidup shopaholic dapat dilihat dari berpengaruhnya mahasiswa dalam menggunakan barang-barang keluaran terbaru. Mahasiswa merasa lebih percaya diri apabila telah memiliki barang-barang keluaran terbaru.

\section{KESIMPULAN}

Dari keseluruhan hasil uraian yang telah dikemukakan berupa hasil penelitian dan pembahasan yang diperoleh dari lapangan dengan menggambarkan dan menganalisa objek kajian, maka penulis dapat menarik suatu kesimpulan yang dijelaskan sebagai berikut :

1. Setelah penulis melakukan penelitian tentang bagaimana pengguna media sosial instagram mendorong perubahan pola pikir perilaku mahasiswa pendidikan sosiologi maka penulis menyimpulkan bahwa ketergantungan akan media instagram dapat membuat seseorang terperangkap pada dunia maya dimana seseorang akan lebih cendrung mementingkan kehidupan maya dibandingkan dengan realita sosialnya.

2. Factor yang mempengaruhi perubahan media sosial instagram terhadap pola pikir perilaku mahasiswa adalah sebagai berikut.

a) Kurangnya pengetahuan tentang media instagram.

b) Kecendrungan menggunakan media istagram secara negative

c) Kecanduan terhadap penggunaan media isntagram

3. Dari hasil penelitian tentang dampak media aplikasi instagram yang dilakukan penelitoi maka dapat disimpulkan bahwa terdapat dua dampak dari perubahan media sosial instagram terhadap pola pikir perilaku mahasiswa yaitu:

a. Dampak positif

Dampak positifnya ialah bisa membantu bagi yang senang mengabadikan moment / peristiwa di sekelilingnya melalui foto, juga dapat menuangkan ide kreatif melalui foto atau mungkin sebagai media promosi dan informasi. Karena 
mengandalkan media visual tentu akan sangat bermanfaat dalam mencari suatu informasi.

b. Dampak Negatif

Saking terlalu banyaknya menggunakan efek instagram dapat memanipulasi orang yang melihatnya.

\section{DAFTAR PUSTAKA}

Abdullah.Aceng. (2000). Press relations, kiat berhubungan dengan media massa. Bandung: Remaja Rosdakarya.

Branen.Julia, (1997).Memandu Penelitian Kualitatif dan Kuantitatif. Yogyakarta: Pustaka Belajar.

Bungin. (2005). Paradigma dan Model Penelitian Komunikasi. Dalam Ardial. Jakarta: Bumi Aksara.

Bungin, Burhan. (2006). Sosiologi Komunikasi: Teori, Paradigma, dan Diskursus Teknologi Komunikasi di Masyarakat. Kencana, Jakarta.

Bogdan dalam Irwan (2015) Metodeanalisis data.

Balack.James dan Dean J. Champion, (1992). Metode dan Masalah Penelitian Sosial. Bandung: Eresco.

com/read/2014/02/19/1623250/Hasil.Survei.Pemakaian.Internet.Remaja.In donesia.http://www.koransindo.com/read/974299/152/unsur-privat-dan-publikdi-path-1425952919 Diakses tanggal 16 juni 2016.

Desyana, Cornila. (2015"). Path Klaim Paling Banyak Penggunaa di Indonesia.http://www.tempo.co/read/news/2014/02/24/061556984/Path-KlaimPaling-Banyak-Pengguna-di-Indonesia, Diakses tanggal 15 juni 2016.

Dwiningrum, S. I. A. (2012). Ilmu sosial \& budaya dasar. Yogyakarta: UNY Press.

Guba dan Lincoln, dalam Sugiono (2006).Metodologi Penelitian. Penerbit Alfabeta

Kominfo.com, (2015). Pengguna Internet di Indonesia 63 Juta Orang. http://kominfo.go.id/index. $\mathrm{php} /$ content/detail/3415/Kominfo+\%3A+Pengguna+Internet+di+Indonesia+63+J uta+Orang/0/berita_satker. Diakses tanggal 16 juni 2016

Koenttjraningrat (1996) Sosiologi perubahan sosial.Jakarta: PT. Raja Grafindo Persada.

Lukman, Enricko. (2014). Laporan 30 Juta Pengguna Internet di Indonesia adalah Remaja.http://id.techinasia.com/laporan-30-juta-pengguna-internet-di indonesia-adalah-remaja/ Diakses tanggal 11 Maret 2016. 
Maryani, E., \& Arifin, H. S. (2012).Konstruksi Identitas Melalui Media Sosial. Journal of Communication Studies, 1(1).

Morissan, dkk. (2010). Teori Komunikasi Massa. Bogor, Ghalia Indonesia. http://tekno.kompas .diakses pada 29 juli 2016

Martono, Nanang. (2012). Sosiologi perubahan sosial: perspektif klasik, modern, postmodern, dan postkolonial. Jakarta: PT. Raja Grafindo Persada.

Milles dan Huberman (1984) dalam buku Metode Penelitian Kualitatif, Kuantitatif dan R\&D dari Sugiyono, 2014:246.

Notoatmodjo, S., (2007), Promosi Kesehatan dan Perilaku.http://www.indonesianpublichealth.com/teori-perilaku-kesehatan/ diakses tanggal 13:04:2015.

Nasrullah, Rulli. (2014). Teori dan Riset Media Siber (Cybermedia). Jakarta : Kencana Prenadamedia Group.

Kriyantono, Rachmat. (2014). Teknik Praktis Riset komunikasi. Jakarta: Kencana Prenada Media Group.

Pasaribu, A. O. H. (2016). Konstruksi Identitas Diri Remaja Pengguna Media Instagram Di Kota Medan.FLOW, 2(18).

M. Tahir Kasnawi dalam Salahuddin (2004) pembangunan sebagai proses perubahan sosial.

Suyanto.Bagong.Sutinah. (2007). Metodologi Penelitian Sosial. Jakarta: Kencana,

Ardial. (2014). Paradigma dan Model Penelitian Komunikasi. Jakarta: Bumi $\quad$ Aksara.

Simarmata.Janer. (2006). Pengenalan Teknologi Komputer dan Informasi. Yogyakarta: Andi.

Tamburaka.Apriadi. (2013). Agenda Setting. Media Massa. Bandung: Remaja Rosdakarya.

Wardani Anindia Pramura. (2015) Konstruksi Diri Dalam Sosial Media.Skripsi Universitas Sebelas Maret Surakarta.

Wright.Chales.(1973). Praktik Ilmu Komunikasi. Dalam Farouk. Muhammad. Jakarta Selatan: Teraju.

Zainuddin, M. (2015) Perubahan Sosial dalam Perspektif Sosiologi Pendidikan. Jawa Pos $\operatorname{him} 8$ 